\title{
Resenha / Extensão Universitária: trajetórias e desafios
}

Ambiente y extensión universitaria / Reseñas (ㄷ)(1)(2)

Deus, Sandra de (2000). Extensão Universitária:

trajetórias e desafios. PRE-UFSM.

Link de acesso: http://hdl.handle.net/10183/216079

Por Alfredo Balduíno Santos

Universidade do Estado de Santa Catarina, Centro de Educação

a Distância, Florianópolis, Santa Catarina, Brasil.

balduinoudesc@gmail.com

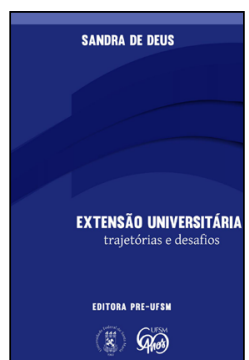

iD orcid.org/0000-0002-1333-585X

O livro Extensão Universitária: trajetórias e desafios da amiga Professora Sandra de Deus é para todas/os as/os extensionistas uma grande contribuição. Sua luta e paixão pela Extensão Universitária ficam evidentes. $O$ texto reflete a organização dos manuscritos de suas palestras ou de outras publicações e nos permitem mergulhar em pensamentos e propostas que colocam à extensão universitária desafios em relação a sua importância na função social das instituições de ensino superior no Brasil. A obra leva a reflexões acerca do tema, que sem dúvidas é a referência de uma vida de dedicação e percepção de uma Universidade integradora e dialógica, num exercício de troca contínua. Onde cada tópico abordado nos possibilita rememorar a luta pessoal e coletiva, de pessoas ligadas e interligadas com as emoções de pensar e caminhar com perseverança, essa trilha com todos os seus obstáculos.

"Extensão Universitária: tecendo diálogos e construindo cenário", busca na extensão, o tempo e definições, na diversidade regional, apesar do pouco reconhecimento. Porém, através do diálogo favorável, referenda os marcos legais da indissociabilidade entre o ensino, a pesquisa e a extensão preconizada constitucionalmente.

Nesta imersão que envolve o recorte temporal, vemos destacada a importância do Fórum de Pró-Reitores de Extensão das Instituições Públicas de Educação Superior Brasileiras, o FORPROEX, comprometido com a formação e transformação social e cidadã, onde discussões ao longo de grandes transformações, por meio de eventos e atividades extensionistas, traduzem essa caminhada em possibilidades para ultrapassar fronteiras na busca por uma Universidade conectada com a realidade. Com base no princípio da indissociabilidade, destaca que a extensão universitária por meio de "um currículo dinâmico, flexível e transformador" pode desconstruir velhos paradigmas pedagógicos para construir uma nova relação com o conhecimento acadêmico, considerando a diversidade em diferentes aspectos. Ao se referir às contribuições para a formação de estudante de graduação, chama a atenção para o grande desafio que envolve a relação entre a universidade e a sociedade, destacando que para tal é necessário desacomodar docentes e estudantes para atuarem em atividades que superem a obrigatoriedade curricular, fazendo com que a universidade com as suas atividades de Extensão, influencie e seja influenciada pelos seus interlocutores com ações proativas.

No texto soberania e integração latino-americana, aborda as contribuições de Córdoba, a elaboração do Estatuto das Universidades Brasileiras, os Movimentos Estudantis e a criação do Projeto Rondon como marcos na mudança do papel da universidade, que dará à extensão universitária um novo status no que refere às questões orçamentárias, bem como 
à prática extensionista que supera a atividade militante de final de semana de professores, técnicos e alunos. A extensão universitária: contribuições para a formação de estudante de graduação aborda as contribuições e possibilidades no processo formativo acadêmico, que pode aproximar a vivência acadêmica da realidade social. Ao mencionar a universidade brasileira e sua inserção social destaca as múltiplas faces em sua inserção social, considerando os marcos da mudança no papel da universidade na América Latina; os sentidos atribuídos à Extensão na universidade e na sociedade e o retorno aos questionamentos e dilemas.

Impacto e transformação social: o papel da extensão universitária faz menção à presença da universidade e da extensão universitária na comunidade, considerando as diretrizes da Extensão: Impacto e Transformação Social, embora ainda se vivencie fortemente o paternalismo e o assistencialismo na sociedade latino-americana. Ainda assim, nos permite perceber os avanços da extensão universitária ao referir a internacionalização e extensão universitária na América Latina que inicia com a criação da Comissão de Relações Internacionais, com três objetivos principais: I) internacionalizar as IFES, incrementando a sua participação em redes internacionais; II) aumentar a mobilidade estudantil, particularmente na graduação; e III) realizar projetos conjuntos com universidades estrangeiras.

Nos 100 anos da reforma de Córdoba, a extensão universitária enfrenta novos desafios como o desenvolvimento sustentável e os desdobramentos de cada um dos 17 ODS, sem esquecer que a universidade é um local de disputa de poder. Contudo, podemos ter como certo que a extensão universitária pode ser o segmento que vai garantir o futuro da universidade, considerando-se a inserção da extensão nos currículos de graduação, embora saibamos da resistência de nossos pares docentes e gestores a possibilidade/obrigatoriedade da Meta 12, estratégia 07 do Plano Nacional de Educação para ser implementada no decênio 2014/2024. 